\title{
Evolution of T-cell clonality in a patient with Ph-negative acute lymphocytic leukemia occurring after interferon and imatinib therapy for Ph-positive chronic myeloid leukemia
}

\author{
Liang Wang ${ }^{1}$, Kanger Zhu ${ }^{1^{*}}$, Xianfeng Zha ${ }^{2}$, Shaohua Chen ${ }^{2}$, Lijian Yang ${ }^{2}$, Si Chen ${ }^{2}$, Yangqiu Li $i^{2,3^{*}}$
}

\begin{abstract}
Introduction: The development of Philadelphia chromosome (Ph) negative acute leukemia/myelodysplastic syndrome (MDS) in patients with Ph-positive chronic myeloid leukemia (CML) is very rare. The features of restrictive usage and absence of partial T cell clones have been found in patients with CML. However, the T-cell clonal evolution of Ph-negative malignancies during treatment for CML is still unknown.

Objective: To investigate the dynamic change of clonal proliferation of T cell receptor (TCR) $V \alpha$ and $\vee \beta$ subfamilies in one CML patient who developed Ph-negative acute lymphoblastic leukemia (ALL) after interferon and imatinib therapy.

Methods: The peripheral blood mononuclear cells (PBMC) samples were collected at the 3 time points (diagnosis of Ph-positive chronic phase (CP) CML, developing Ph-negative ALL and post inductive chemotherapy (CT) for Ph-negative ALL, respectively). The CDR3 size of TCR V $\alpha$ and $V \beta$ repertoire were detected by RT-PCR. The PCR products were further analyzed by genescan to identify $T$ cell clonality.

Results: The CML patient who achieved complete cytogenetic remission (CCR) after 5 years of IFN- $\alpha$ therapy suddenly developed Ph-negative ALL 6 months following switch to imatinib therapy. The expression pattern and clonality of TCR $V \alpha N \beta$ T cells changed in different disease stages. The restrictive expression of $V \alpha / \beta$ subfamilies could be found in all three stages, and partial subfamily of T cells showed clonal proliferation. Additionally, there have been obvious differences in $V \alpha / N \beta$ subfamily of $T$ cells between the stages of Ph-positive CML-CP and Ph-negative ALL. The V $\alpha 10$ and $V \beta 3 T$ cells evolved from oligoclonality to polyclonality, the V $\beta 13 T$ cells changed from bioclonality to polyclonality, when Ph-negative ALL developed.

Conclusions: Restrictive usage and clonal proliferation of different $V \alpha / N \beta$ subfamily $T$ cells between the stages of $\mathrm{Ph}$-positive CP and Ph-negative ALL were detected in one patient. These changes may play a role in Ph- negative leukemogenesis.
\end{abstract}

\section{Introduction}

Chronic myeloid leukemia (CML) is genetically characterized by the presence of the reciprocal translocation $t$ $(9 ; 22)$ (q34; q11), resulting in a BCR/ABL gene fusion on the derivative chromosome 22 called the Philadelphia chromosome (Ph). Blastic transformation (BT) remains a

\footnotetext{
* Correspondence: tzhuker@jnu.edu.cn; yangqiuli@hotmail.com 'Department of Hematology, First Affiliated Hospital, Jinan University, Guangzhou, 510632, PR China

${ }^{2}$ Institute of Hematology, Medical College, Jinan University, Guangzhou,
} 510632, PR China dire outcome of CML patients with a poor prognosis. Non-random additional chromosome abnormalities accompanied by Philadelphia chromosome can be detected in $60-80 \%$ of cases in BT [1]. Recently, however, the development of chromosomal abnormalities in $\mathrm{Ph}$-negative cells [2] and isolated instances of Ph-negative acute leukemia or high-risk MDS during treatment for CML have been reported [2-10]. The clonal origin of $\mathrm{Ph}$-negative leukemic clone is still unknown,. It is possible that it may originate from a de novo leukemic stem 
cell (malignant clone) due to therapy related toxicity such as interferon, imatinib or other agents.

$\mathrm{T}$ cell immunodeficiency was suggested to play an important role in tumor patients by facilitating the expansion of a malignant clone [11,12]. Clonally expanded T-cells were identified in peripheral blood or tumor infiltrating T-cells (TIL), which are thought to play a pivotal role in the adaptive immune responses by recognizing antigen- derived peptides bound to MHC molecules. The clonality of $\mathrm{T}$-cells could be identified by analysis of CDR3 size of 24 TCR V $\beta$ genes using RTPCR and genescan, which is called "immunoscope" $[13,14]$. Several studies on TCR V $\beta$ repertoire showed that skewed expression of TCR V $\beta$ subfamilies is a common feature in leukemia patients [15-18]. Clonally expanded $\mathrm{T}$ cells with restricted TCR V $\beta$ usage can recognize tumor cells in patients with both solid tumors and leukemia $[16,19,20]$.

It has been reported that leukemia-associated antigen can induce specific clonal expansion of host T-cells or the allogeneic $\mathrm{T}$-cells. These activated $\mathrm{T}$-cells have been shown to display potential cytotoxic activity against primary leukemic cells. Thus, it may be useful for eradication of minimal residual leukemic cells by activating autologous or allogeneic cytotoxic cells. In particular, specific CTLs may be a promising tool in the treatment of myelogenous leukemia $[16,17,21]$. Our previous study showed that clonal expansion of $\mathrm{T}$-cells could be induced by CML associated antigen [16]. However, it is unclear how the clonally expanded TCR $\mathrm{V} \beta \mathrm{T}$-cells in CML patients are related to the development of Ph-negative acute leukemia. In the present study, we have used reverse transcription polymerase chain reaction (RT-PCR) and the genescan analysis to assay for TCR $V \alpha$ and $V \beta$ gene utilization and clonal expansion in a patient who developed $\mathrm{Ph}$-negative acute lymphoblastic leukemia while in CML complete remission following interferon and imatinib mesylate therapy.

\section{Methods}

\section{Case history}

A 10-year-old female presented to our hospital in October 2000 because of excessive tiredness, epistaxis and weight loss. Examination revealed moderate hepatosplenomegaly, and a blood count showed hemoglobin 102 g/L, white cell count $179 \times 10^{9} / \mathrm{L}$, blasts $1 \%$, promyelocytes $8 \%$, myelocytes $10 \%$, metamyelocytes $29 \%$, eosinophils $1 \%$, basophils $7 \%$, bands $16 \%$, polymorphs $26 \%$, lymphocytes $2 \%$ and platelets $917 \times 10^{9} / \mathrm{L}$. Leukocyte alkaline phosphatase was 11 . Bone marrow examination was consistent with chronic phase CML (CML-CP). Cytogenetic studies showed $25 / 25$ cells with 46 , XX, $t(9 ; 22), t(11 ; 18)$, der(16), $t(16 ;$ ?) by R-banding technique.
Fluorescence in situ hybridization (FISH) and reverse transcription polymerase chain reaction (RT-PCR) studies for BCR/ABL fusion gene were positive. She received interferon-alpha (IFN- $\alpha$ ) combined with hydroxyurea therapy. Hydroxyurea was discontinued three weeks later, when white cell count decreased to $5.7 \times$ $10^{9} / \mathrm{L}$, and spleen and liver became non-palpable. Treatment with IFN- $\alpha$ was commenced at a dose of 1.5 million-units $(\mathrm{MU}) /$ day. BCR/ABL fusion gene remianed positive $(90 \% \sim 100 \%)$ by FISH analysis, which was performed once or twice per year from 2001 to 2005. In May 2005, we boosted the dose of IFN- $\alpha$ from 1.5 to $3 \mathrm{MU} /$ day. Unfortunately, the patient failed to tolerate full-dose IFN- $\alpha$ due to leukopenia $\left(1 \times 10^{9} / \mathrm{L}\right)$ complicated with fever. We discontinued IFN- $\alpha$ therapy for 3 months. After this, the dose of IFN- $\alpha$ ranged from 1.5 to $3 \mathrm{MU}$ per week according to white cell count. In January 2006, FISH analysis revealed that the patient achieved complete cytogenetic remission (CCR). At this time, IFN- $\alpha$ was stopped, and imatinib mesylate (IM, $400 \mathrm{mg} / \mathrm{d}$ ) was given instead according to the patient's selection. BCR/ABL fusion gene was detected using FISH analysis of marrow samples in March, May and August 2006.

In October 2006, the patient was admitted to our department again due to sudden onset of overall osteodynia, especially both in lower extremities, sternum and ribs. A blood count showed hemoglobin $102 \mathrm{~g} / \mathrm{L}$, white cell count $5.72 \times 10^{9} / \mathrm{L}$, myelocytes $1 \%$, bands $14 \%$, polymorphs $24 \%$, monocytes $12 \%$, eosinophils $1 \%$, lymphocytes $48 \%$ and platelets $75 \times 10^{9} / \mathrm{L}$. Bone marrow smear revealed 95\% blasts that expressed CD34, HLA-DR and the lymphoid antigens CD19, CD20 and CD10. The blasts were myeloperoxidase negative by cytochemistry staining, and cytogenetic analysis showed 25/25 cells with 46, XX. Repeat FISH analysis of this sample confirmed 200/200 metaphase cells to be Ph-negative. After receiving two courses of induction chemotherapy consisting of CMOP regimen (cyclophosphamide, mitoxantone, vincristine and prednisone) and FLAG regimen (fludarabine, cytoarabine and granulocyte-cloning stimulating factor), respectively, the patient achieved complete remission (CR). Unfortunately bone marrow aspirate performed four weeks later showed relapse with $67 \%$ lymphoblasts. The karyotype was still normal, and BCR/ABL fusion gene was still negative by FISH. The patient was treated palliatively and died of pulmonary invasive fungi infection in June 2007.

\section{Samples}

After the patient's consent, the bone marrow and peripheral blood samples were collected in three different disease stages of Ph-positive CP-CML, Ph-negative ALL 
and post two courses of chemotherapy (CT) for Ph-negative ALL, respectively.

\section{Cytogenetic, FISH and RT-PCR analysis for BCR/ABL detection}

Karyotype analyses were performed by R-banding technique. FISH was performed using LSI.bcr/abl dual color probe (Vysis) that identified $B C R / A B L$ rearrangement derived from $\mathrm{t}(9 ; 22)$ ( $\mathrm{q} 34 ; \mathrm{q} 11.2)$. Three primers of RT-PCR analyses for BCR/ABL detection were listed in Table 1, and PCR was performed as described by Kawasaki ES et al [22].

\section{Peripheral blood mononuclear cells (PBMC) isolation, RNA isolation and CDNA synthesis}

PBMC were isolated by Ficoll-Hypaque gradient centrifugation. RNA was extracted from the PBMC samples according to the manufacturer's recommendations (Trizol, Gibco, USA): The quality of RNA was analyzed in $0.8 \%$ agarose gel stained with ethidium bromide. Two $\mu \mathrm{g}$ RNA was reversely transcribed into the first singlestrand cDNA with random hexamer primers, using reverse transcriptase, Superscript II Kit (Gibco, USA). The quality of cDNA was confirmed by RT-PCR for $\beta 2$ microglubin gene amplification.

\section{RT-PCR for TCR V $\boldsymbol{\alpha}$ and TCR V $\beta$ subfamily amplification}

29 sense TCR V $\alpha$ primers and a single TCR C $\alpha$ reverse primer, or 24 TCR V $\beta$ sense primers and a single TCR $C \beta$ primer were used in unlabeled PCR for amplification of the TCR V $\alpha$ and V $\beta$ subfamilies respectively [23]. Subsequently, a runoff PCR was performed with fluorescent primers labelled at 5' end with the FAM fluorophore $(\mathrm{C} \alpha-\mathrm{FAM}$ or $\mathrm{C} \beta-\mathrm{FAM})$ purchased from TIB MOLBIOL GmbH, Berlin, Germany. PCR was performed as described by Puisieux I et al and our previous studies $[16,23,24]$. Aliquots of the cDNA $(1 \mu \mathrm{l})$ were amplified in $25 \mu \mathrm{l}$ reactions with one of the $29 \mathrm{V \alpha}$ primers and a $\mathrm{C} \alpha$ primer or one of $24 \mathrm{~V} \beta$ primers and a $\mathrm{C} \beta$ primer. The final reaction mixture contained $0.5 \mu \mathrm{M}$ sense primer and antisense primer, $0.1 \mathrm{mM}$ dNTP, 1.5 $\mathrm{mM} \mathrm{MgCl} 2,1 \times \mathrm{PCR}$ buffer and $1.25 \mathrm{U}$ Taq polymerase (Promega, USA). The amplification was performed on a DNA thermal cycler (BioMetra, Germany). After 3 min denaturation at $94^{\circ} \mathrm{C}, 40 \mathrm{PCR}$ cycles were performed, each cycle consisting of $94^{\circ} \mathrm{C}$ for $1 \mathrm{~min}, 60^{\circ} \mathrm{C}$ for $1 \mathrm{~min}$

Table 1 The sequence of primers used for detection of BCR/ABL rearrangement

\begin{tabular}{ll}
\hline Primers & Sequences \\
\hline CML 1 (upstream) & 5'-GGAGCTGCAGATGCTGACCAAC-3' \\
CML 2 (downstream) & 5'-TCAGACCCTGAGGCTCAAAGTC-3' \\
CML 3 (upstream) & 5'-CGCATGTTCCGGGACAAAAGC-3' \\
\hline
\end{tabular}

and $72^{\circ} \mathrm{C}$ for $1 \mathrm{~min}$, and a final $7 \mathrm{~min}$ elongation at $72^{\circ}$ C. Then, the products were stored at $4^{\circ} \mathrm{C}$.

\section{Genescan analysis for TCR V $\alpha$ and TCR V $\beta$ subfamily clonality analysis}

Aliquots of the unlabeled PCR products $(2 \mu \mathrm{l})$ were subjected to a cycle of runoff reaction with fluorophorelabelled $C \alpha$-fam or $C \beta$-fam primer respectively. The labelled runoff PCR products $(2 \mu \mathrm{l})$ were heat-denatured at $94^{\circ} \mathrm{C}$ for $4 \mathrm{~min}$ with $9.5 \mu \mathrm{l}$ formamide (Hi-Di Formamide, ABI, USA) and $0.5 \mu \mathrm{l}$ of Size Standards (GENES$\mathrm{CAN}^{\mathrm{Tm}}-500-\mathrm{LIZ}^{\mathrm{rm}}$, Perkin Elmer, ABI), the samples were then loaded on 3100 POP $-4^{\mathrm{TM}}$ gel (Performance Optimized Polymer-4, ABI, USA) and resolved by electrophoresis in 3100 DNA sequencer (ABI, Perkin Elmer) for size and fluorescence intensity determination using Genescan software [16,23,24].

\section{Results}

\section{Genetic feature of the CML case}

Clinical, cytogenetic and molecular features of different disease stage in this patient were listed in Table 2. Cytogenetic studies showed $25 / 25$ cells with $46, \mathrm{XX}, \mathrm{t}(9 ; 22)$, $\mathrm{t}(11 ; 18)$, der(16), $\mathrm{t}(16 ;$;) by $\mathrm{R}$-banding technique at the diagnosis of CP-CML in October 2000. FISH and RTPCR studies for BCR/ABL fusion gene were also positive. In October 2006, when the patient was diagnosed to have ALL, she had normal karyotype and negative FISH and RT-PCR studies for BCR/ABL (Figure 1).

\section{TCR V $\alpha$ and TCR V $\beta$ repertoire in PB T-cells}

In different disease stage, the expression pattern of $\mathrm{V} \alpha$ and $\mathrm{V} \beta$ repertoires was different. Only 9, 13 and 4 TCR $\mathrm{V} \alpha$ subfamilies were detected in PBMCs from the disease stage of CP-CML, ALL and post CT for ALL, respectively. TCR V $\beta$ subfamilies 4,18 and 7 were detected in PBMCs from the disease stage of CP-CML, ALL and post $\mathrm{CT}$, respectively, whereas almost all $\mathrm{V} \alpha$ and $\mathrm{V} \beta$ subfamilies could be detected in healthy controls. When patient developed ALL, 6 TCR V $\alpha$ and 14 TCR V $\beta$ subfamilies were newly expressed, and 2 TCR $\mathrm{V} \alpha$ (Vo4 and $\mathrm{V} \alpha 8$ ) subfamilies disappeared (Figure 2 and 3 ).

\section{The clonality of TCR V $\alpha / V \beta$ subfamily T-cells in different disease stages}

Polyclonality of $\mathrm{T}$ cells representing random rearrangement of TCR genes were detected in most TCR V $\alpha / \mathrm{V} \beta$ subfamily in PBMCs of the patient in different disease stages. Clonal expansion of TCR V $\beta$ repertoire could be found in some TCR V $\beta$ subfamilies, which displayed different pattern between CT and ALL. V $\beta 13$ or V $\beta 9$ and $\mathrm{V} \beta 17$ were identified at the stage of $C T$ and ALL respectively. More oligoclonal TCR V $\beta$ T cells were detected after CT for ALL in the patient (Figure 4 and 5). 
Table 2 Clinical, cytogenetic and molecular features of a patient with Ph-positive CML who developed Ph-negative acute lymphoblastic leukemia after IFN- $\alpha$ and imatinib mesylate therapy

\begin{tabular}{|c|c|c|c|c|}
\hline \multirow[t]{2}{*}{ Date } & \multirow{2}{*}{$\begin{array}{l}\text { Disease stage } \\
\text { (Treatment) }\end{array}$} & \multirow[t]{2}{*}{ Karyotype } & \multicolumn{2}{|c|}{$\mathrm{BCR} / \mathrm{ABL}$} \\
\hline & & & $\overline{\mathrm{FISH}}$ & RT-PCR \\
\hline $8 / 10 / 2000$ & $\mathrm{CP}$ & $46, X X, t(9 ; 22), t(11 ; 18), \operatorname{der}(16), t(16 ; ?)[25]$ & + ve(95\%) & + ve \\
\hline $3 / 3 / 2001$ & $C P(I F N-\alpha)$ & ND & +ve(95\%) & ND \\
\hline $21 / 12 / 2001$ & $C P(I F N-\alpha)$ & $\begin{array}{l}45, X X,-22,16 \mathrm{q}+\mathrm{t}(11 ; 18)[1] / 45, X X,-22,16 \mathrm{q} \\
+\mathrm{t}(9 ; 22) \mathrm{t}(11 ; 18)[1] / 46, X X,-22,16 \mathrm{q}+\mathrm{t} \\
(9 ; 22) \mathrm{t}(11 ; 18)[18] / 46, X X[5]\end{array}$ & +ve(90\%) & ND \\
\hline $28 / 11 / 2002$ & $C P(I F N-\alpha)$ & ND & $+v e(100 \%)$ & ND \\
\hline 28/11/2003 & $C P(I F N-\alpha)$ & ND & +ve(90\%) & ND \\
\hline $6 / 5 / 2004$ & $C P(I F N-\alpha)$ & ND & +ve(90\%) & ND \\
\hline $1 / 6 / 2005$ & $C P(I F N-\alpha)$ & ND & $+\operatorname{ve}(75 \%)$ & ND \\
\hline 27/1/2006 & $C C R(I F N-\alpha)$ & ND & -ve & ND \\
\hline $8 / 3 / 2006$ & CCR (IM) & ND & -ve & ND \\
\hline $11 / 5 / 2006$ & CCR (IM) & ND & -ve & ND \\
\hline $9 / 8 / 2006$ & CCR (IM) & ND & -ve & ND \\
\hline 8/10/2006 & Ph-negative ALL & $46, X X[25]$ & -ve & -ve \\
\hline $18 / 12 / 2006$ & Post CT for ALL & $46, X X[25]$ & -ve & -ve \\
\hline
\end{tabular}

CP: chronic phase; ALL: acute lymphoblastic leukemia; CCR: complete cytogenetic response; Hu: hydroxyurea; IM: imatinib mesylate; CT: chemotherapy; +ve: positive; -ve: negative; ND: not done.

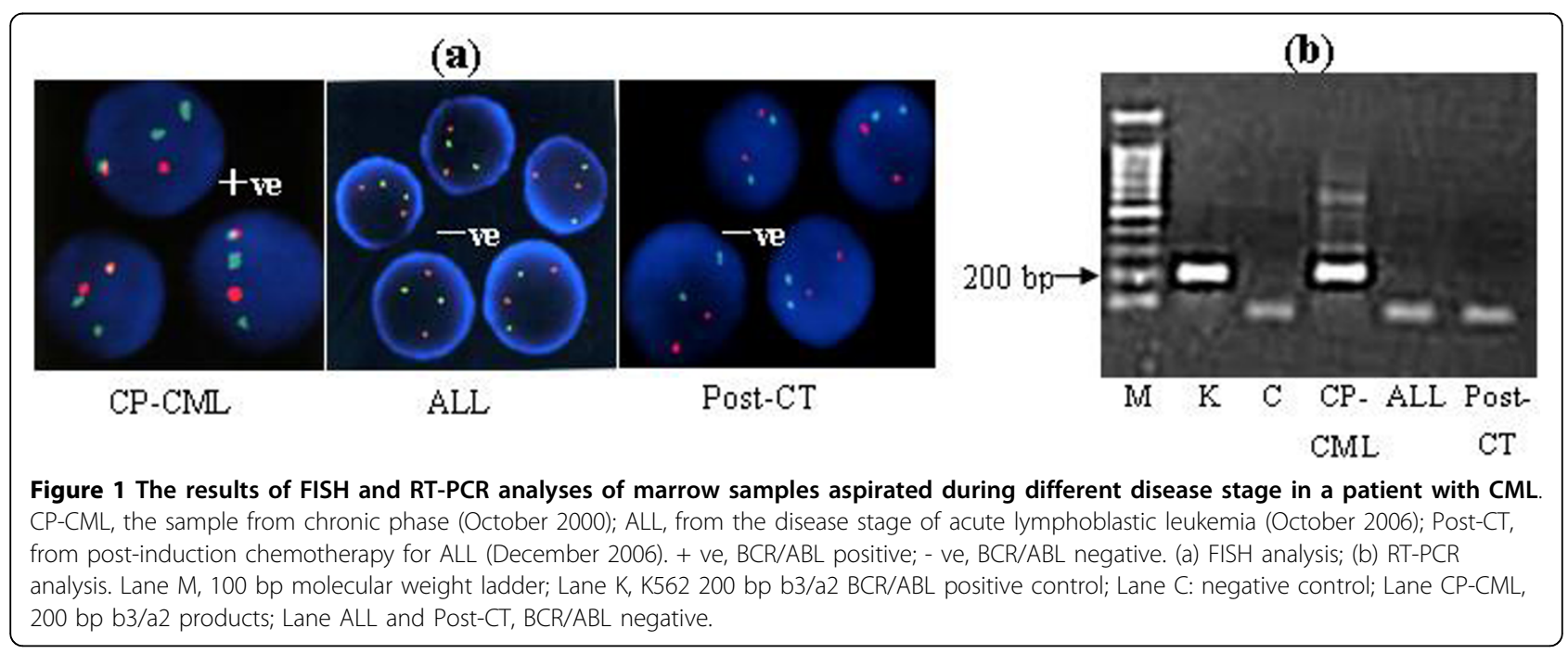

\section{Discussion}

Isolated instances of $\mathrm{Ph}$-negative acute leukemia or high-risk MDS have been observed in the course of interferon- $\alpha[4,9]$ and imatinib therapy $[2,3]$ or post hematopoietic stem cell transplantation [5] for Ph-positive CML. In the present study, we reported a similar case which developed $\mathrm{Ph}$-negative acute lymphoblastic leukemia following imatinib therapy for 6 months. It was thought that the $\mathrm{Ph}$-negative leukemic cells might originate from a new malignant clone rather than previous $\mathrm{Ph}$-positive clone [25]. The cause of this phenomenon remains unclear. In the present study, we characterized the T-cell repertoires between the stages of CML-CP and Ph- negative ALL. Our previous studies showed that the clonally expanded $\mathrm{T}$ cells were associated with a leukemia associated antigen [16]. The newly generated malignant clone might express different leukemia specific or associated antigen, which may induce different response of TCR repertoire pattern. It would be interesting to detect the evolution of T-cell clonality in the patient at different disease status.

The features of restrictive usage and absence of partial $\mathrm{T}$ cell clones could be found in patients with CML [26], which indicate deficiency of cellular immunity in CML patients. However, on the other hand, anti-CML cytotoxic $\mathrm{T}$-cell clones were also identified in patients 


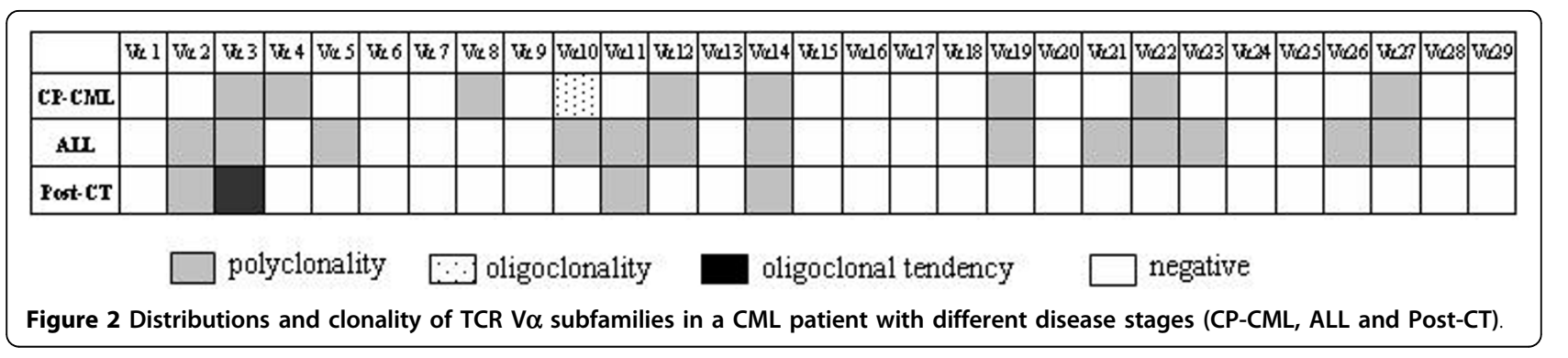

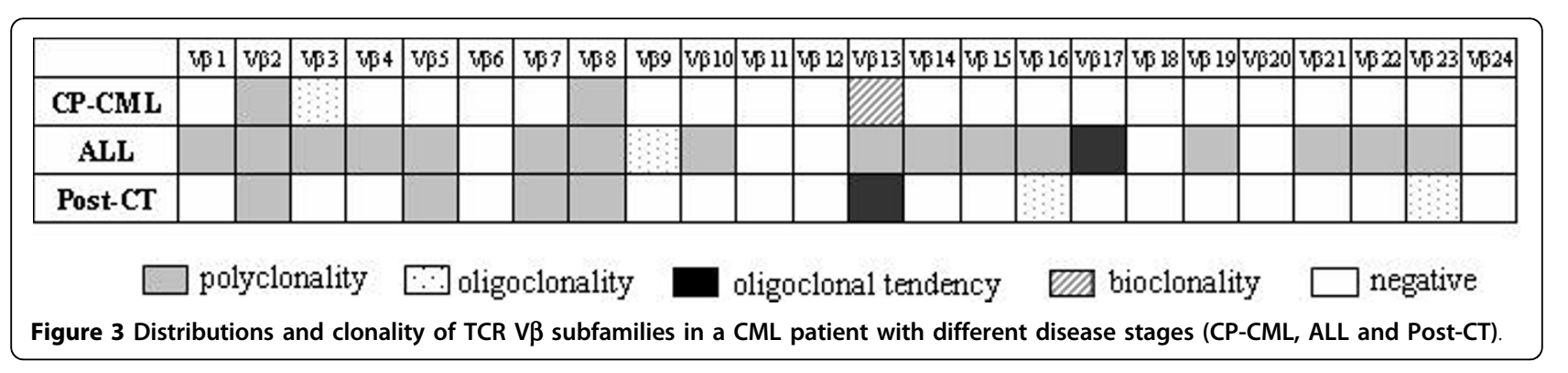

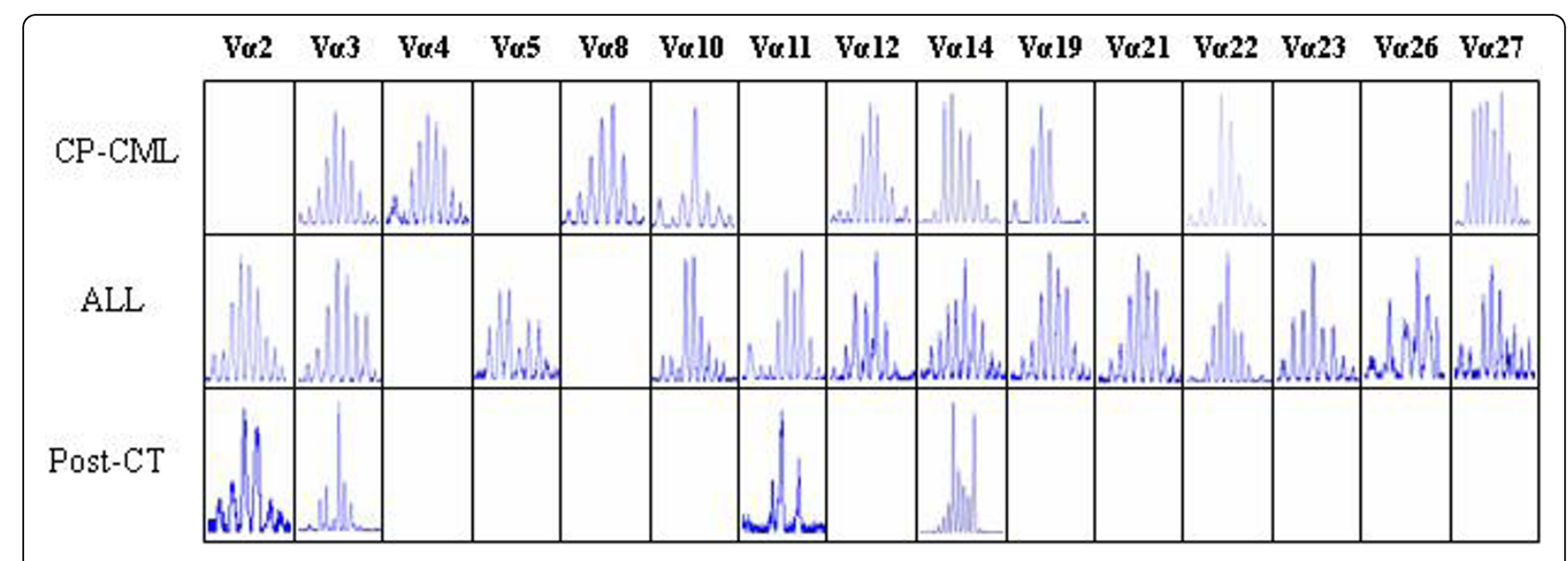

Figure 4 The results of genescan of TCR V $\alpha$ subfamilies in a CML patient with different disease stages (CP-CML, ALL and Post-CT).

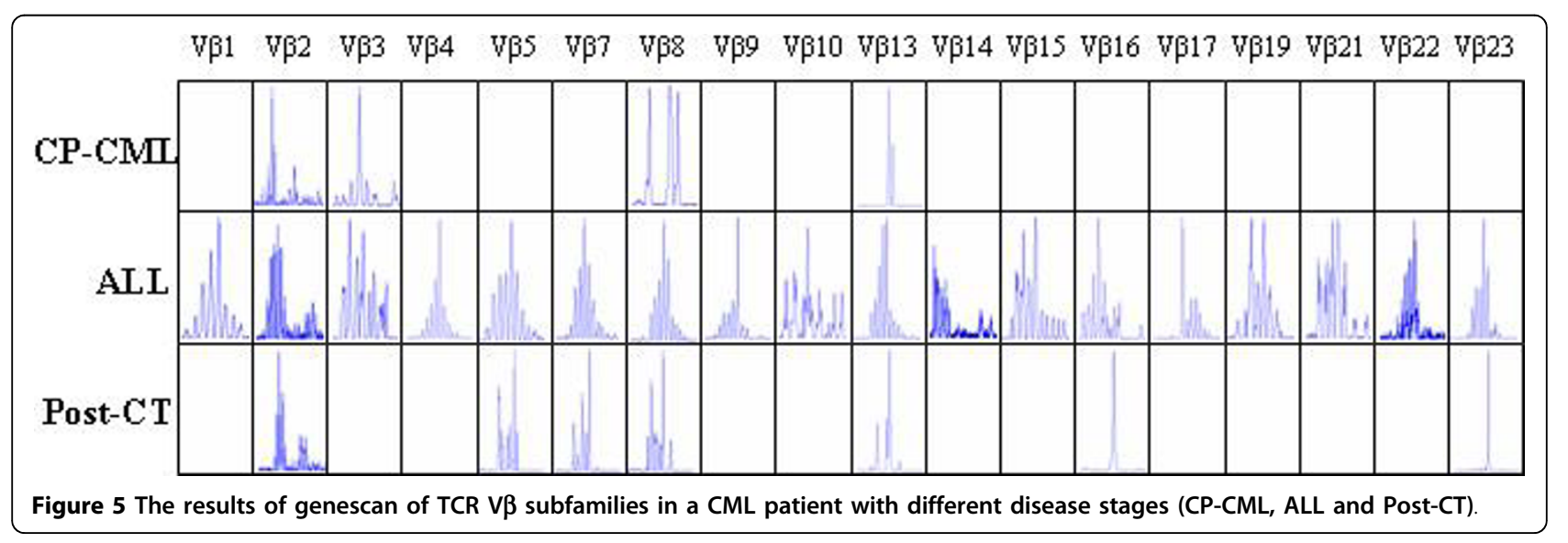


with CML. These specific CTLs could be detected in T cells from peripheral blood of CML patients or autologous $\mathrm{T}$ cells inducted by bcr-abl peptide and so on [15]. In the present study, the TCR $V \alpha$ and $V \beta$ distribution and $\mathrm{T}$ cell clonality were analyzed by RT-PCRgenescan technique in a CML patient with different disease stages. As expected, there are marked difference in the expressional number of TCR $V \alpha / \mathrm{V} \beta$ between the disease stage of $\mathrm{CP}$ and that of Ph-negative ALL. Only 9 of all $29 \mathrm{~V} \alpha$ and 4 of all $24 \mathrm{~V} \beta$ subfamilies could be detected at the time of $\mathrm{CP}$, while $13 / 29$ $\mathrm{V} \alpha$ and $18 / 24 \mathrm{~V} \beta$ subfamilies could be found at the time of Ph-negative ALL. Additionally, decreased number of TCR V $\alpha / V \beta$ subfamilies was detected post chemotherapy. The distinct distribution of clonal $\mathrm{T}$ cells were also detected in different disease stage, the pattern changes in the clonally expanded $\mathrm{T}$ cells between the chronic phase CML and Ph-negative acute lymphoblastic leukemia might represent the change of the host cellular immune response. Obviously, the predominant usage of TCR V $\beta$ subfamilies were TCR V $\beta 3$ and $\mathrm{V} \beta 13$ in oligoclonal expanded $\mathrm{T}$ cells from CML$\mathrm{CP}$, while the usage pattern changed to TCR V $\beta 9$ and $\mathrm{V} \beta 17$, when acute lymphoblastic leukemia developed. This phenomenon may be caused by leukemic antigen variation due to leukemia clonal change from a Phpositive clone to a $\mathrm{Ph}$-negative clone. Although the antigenic peptides leading to clonal $\mathrm{T}$-cell selection in CML are unknown, the change of TCR V $\beta$ clones might provide the information for host immune response. After two courses of chemotherapy for Phnegative ALL, the decrease of TCR subfamilies including $\mathrm{V} \alpha$ and $\mathrm{V} \beta$ were possibly induced by chemotherapy. There are two possible mechanisms to interpret the occurrence of oligoclonal $\mathrm{T}$ cells, including immunity response to novel leukemic antigen and immunosuppression by chemotherapy.

In the present study, oligoclonally- expanded $\mathrm{T}$ cells seem unmarked, when the TCR V $\alpha$ repertoire analysis was used. Oligoclonally- expanded T cells was found only in Va10 subfamily in CML-CP, which changed to polyclonally expanded $\mathrm{T}$ cells in ALL. It may indicate that the polyclonally expanded pattern was a common feature in TCR V $\alpha$ subfamily T cells. Thus, the TCR V $\beta$ repertoire analysis was thought more sensitive for detecting clonally expanded $\mathrm{T}$ cells in immune response, at least, in the present CML case.

To our knowledge, this is the first investigation of $\mathrm{T}$-cell clonal changes in Ph-negative ALL and Ph-positive CML in the same patient. More cases of secondary $\mathrm{Ph}$-negative leukemia/MDS are needed to better characterize the clonal expansion and evolution of T-cell repertoire.

\section{Conclusions}

Restrictive usage and clonal proliferation of different $\mathrm{V} \alpha /$ $\mathrm{V} \beta$ subfamily $\mathrm{T}$ cells between the stages of Ph-positive $\mathrm{CP}$ and Ph-negative ALL were detected in one patient. These changes may play a role in $\mathrm{Ph}$ - negative leukemogenesis.

\section{Acknowledgements}

The project was sponsored by grants from the National "863" projects of China (2006AA02Z114) and the Natural Science Foundation of Guangdong province (No. 05103293 and 9251063201000001 )

\section{Author details}

'Department of Hematology, First Affiliated Hospital, Jinan University, Guangzhou, 510632, PR China. ${ }^{2}$ Institute of Hematology, Medical College, Jinan University, Guangzhou, 510632, PR China. ${ }^{3}$ Key Laboratory for Regenerative Medicine of Ministry of Education, Jinan University, Guangzhou, 510632, PR China.

\section{Authors' contributions}

LW, YQL and KEZ were responsible for study design and data management. LW and XFZ collected samples, recorded all clinical data, and detected the CDR3 size of TCR $V \alpha$ and $\vee \beta$ repertoire RT-PCR. LW, SHC and SC carried out genescan. YQL, KEZ and LJY participated together with LW in editing the manuscript. All authors read and approved the final manuscript.

\section{Competing interests}

The authors declare that they have no competing interests.

Received: 2 December 2009 Accepted: 9 April 2010

Published: 9 April 2010

\section{References}

1. Johansson B, Fioretos T, Mitelman F: Cytogenetic and molecular genetic evolution of chronic myeloid leukemia. Acta Haematol 2002, 107:76-94.

2. Kovitz C, Kantarjian H, Garcia-Manero G, Abruzzo LV, Cortes J: Myelodysplastic syndromes and acute leukemia developing after imatinib mesylate therapy for chronic myeloid leukemia. Blood 2006, 108:2811-2813.

3. Au WY, Lie AK, Ma SK, Wan TS, Liang R, Leung YH, Kwong YL: Philadelphia $(\mathrm{Ph})$ chromosome-positive chronic myeloid leukaemia relapsing as $\mathrm{Ph}$-negative leukaemia after allogeneic bone marrow transplantation. Br J Haematol 2001, 114:365-368.

4. Bose S, Chowdhry VP, Saxena R, Kucheria K: Lymphoid blast crisis during complete cytogenetic remission following interferon-alpha and hydroxyurea therapy. Acta Haematol 1997, 98:155-159.

5. Cullen MJ, Richards SJ, Dickinson H, Carter C, Swirsky DM, Owen RG: Development and progression of a Philadelphia-chromosome-negative acute myelocytic leukemia clone in a patient with Philadelphiachromosome-positive chronic myelocytic leukemia. Cancer Genet Cytogenet 2004, 148:170-173.

6. Dawson L, Slater R, Hagemeijer A, Langerak AW, Willemze R, KluinNelemans JC: Secondary T-acute lymphoblastic leukaemia mimicking blast crisis in chronic myeloid leukaemia. Br J Haematol 1999, 106:104-106.

7. Flamm MJ, Murty W, Rao PH, Nichols GL: Coexistence of independent myelodysplastic and Philadelphia chromosome positive clones in a patient treated with hydroxyurea. Leuk Res 2002, 26:417-420.

8. Manley R, Cochrane J, McDonald M, Rigby S, Moore A, Kirk A, Clarke S, Crossen PE, Morris CM, Patton WN: Clonally unrelated BCR-ABL-negative acute myeloblastic leukemia masquerading as blast crisis after busulphan and interferon therapy for BCR-ABL-positive chronic myeloid leukemia. Leukemia 1999, 13:126-129.

9. Ohtsuka E, Kikuchi H, Abe Y, Moriyama K, Ohno E, Hirota K, Tezono K, Nasu M: Acute myeloblastic leukaemia without Philadelphia chromosome developing after interferon therapy for chronic myelocytic leukaemia with Philadelphia chromosome. Br J Haematol 1995, 90:951-953. 
10. Zhang X, Ji L, Liu S, Wang J: Ph-negative acute lymphocytic leukemia occurring after interferon therapy for Ph-positive chronic myelocytic leukemia. Leuk Res 2003, 27:367-369.

11. Costello RT, Rey J, Fauriat C, Gastaut JA, Olive D: New approaches in the immunotherapy of haematological malignancies. Eur J Haematol 2003, 70:333-345.

12. Hadden JW: Immunodeficiency and cancer: prospects for correction. Int Immunopharmacol 2003, 3:1061-1071.

13. Pannetier C, Even J, Kourilsky P: T-cell repertoire diversity and clonal expansions in normal and clinical samples. Immunol Today 1995, 16:176-181.

14. Romero P, Cerottini JC, Waanders GA: Novel methods to monitor antigenspecific cytotoxic T-cell responses in cancer immunotherapy. Mol Med Today 1998, 4:305-312.

15. Li Y: Leukemia associated clonal expansion of TCR Vbeta subfamily T cells. Hematology 2003, 8:375-384.

16. Li Y, Yang L, Chen S, Zhang Y, Wu X: The TCR Vbeta repertoire usage of T-cells from cord blood induced by chronic myelogenous leukemia associated antigen. Hematology 2005, 10:387-392.

17. Rezvany MR, Jeddi-Tehrani M, Osterborg A, Kimby E, Wigzell H, Mellstedt $\mathrm{H}$ : Oligoclonal TCRBV gene usage in B-cell chronic lymphocytic leukemia: major perturbations are preferentially seen within the CD4 T-cell subset. Blood 1999, 94:1063-1069.

18. Rezvany MR, Jeddi-Tehrani M, Wigzell $H$, Osterborg A, Mellstedt $H$ : Leukemia-associated monoclonal and oligoclonal TCR-BV use in patients with B-cell chronic lymphocytic leukemia. Blood 2003, 101:1063-1070.

19. Mami-Chouaib F, Echchakir H, Dorothee G, Vergnon I, Chouaib S: Antitumor cytotoxic T-lymphocyte response in human lung carcinoma: identification of a tumor-associated antigen. Immunol Rev 2002, 188:114-121.

20. thor Straten $P$, Guldberg $P$, Gronbaek K, Hansen MR, Kirkin AF, Seremet T, Zeuthen J, Becker JC: In situ T cell responses against melanoma comprise high numbers of locally expanded T cell clonotypes. J Immunol 1999, 163:443-447.

21. Serrano D, Monteiro J, Allen SL, Kolitz J, Schulman P, Lichtman SM, Buchbinder A, Vinciguerra VP, Chiorazzi N, Gregersen PK: Clonal expansion within the CD4+CD57+ and CD8+CD57+ T cell subsets in chronic lymphocytic leukemia. J Immunol 1997, 158:1482-1489.

22. Kawasaki ES, Clark SS, Coyne MY, Smith SD, Champlin R, Witte ON, McCormick FP: Diagnosis of chronic myeloid and acute lymphocytic leukemias by detection of leukemia-specific mRNA sequences amplified in vitro. Proc Natl Acad Sci USA 1988, 85:5698-5702.

23. Li Y, Chen S, Yang L, Yin Q, Geng S, Wu X, Schmidt CA, Przybylski GK: TRAV and TRBV repertoire, clonality and the proliferative history of umbilical cord blood T-cells. Transpl Immunol 2007, 18:151-158.

24. Puisieux I, Even J, Pannetier C, Jotereau F, Favrot M, Kourilsky P: Oligoclonality of tumor-infiltrating lymphocytes from human melanomas. J Immunol 1994, 153:2807-2818.

25. Fayad L, Kantarjian H, O'Brien S, Seong D, Albitar M, Keating M, Talpaz M: Emergence of new clonal abnormalities following interferon-alpha induced complete cytogenetic response in patients with chronic myeloid leukemia: report of three cases. Leukemia 1997, 11:767-771.

26. Li YQ, Yang LJ, Chen SH, Zhang YP, Zhang XL, Luo GX: T cell receptor Vbeta repertoire usage and clonal expansion of $\mathrm{T}$ cells in chronic myelogenous leukemia. Chin Med J (Engl) 2004, 117:840-843.

doi:10.1186/1756-8722-3-14

Cite this article as: Wang et al.: Evolution of T-cell clonality in a patient with $\mathrm{Ph}$-negative acute lymphocytic leukemia occurring after interferon and imatinib therapy for Ph-positive chronic myeloid leukemia. Journal of Hematology \& Oncology 2010 3:14.

\section{Submit your next manuscript to BioMed Central and take full advantage of:}

- Convenient online submission

- Thorough peer review

- No space constraints or color figure charges

- Immediate publication on acceptance

- Inclusion in PubMed, CAS, Scopus and Google Scholar

- Research which is freely available for redistribution

Submit your manuscript at www.biomedcentral.com/submit
Biomed Central 